\title{
Propolis in Dogs: Clinical Experiences and Perspectives (A Brief Review)
}

\author{
Nelly Tovar Betancourt1, Lucila García-Contreras², Tonatiuh Alejandro Cruz Sánchez1 \\ ${ }^{1}$ Facultad de Estudios Superiores Cuautitlán, Universidad Nacional Autónoma de México, \\ Cuautitlán Izcalli, México \\ ${ }^{2}$ Department of Pharmaceutical Sciences, The University of Oklahoma Health Sciences Center, \\ Oklahoma City, USA \\ Email: nellytovarbetancourt@hotmail.com
}

Received 1 December 2014; accepted 14 December 2014; published 15 January 2015

Copyright (C) 2015 by authors and Scientific Research Publishing Inc.

This work is licensed under the Creative Commons Attribution International License (CC BY). http://creativecommons.org/licenses/by/4.0/

(c) (i) Open Access

\begin{abstract}
In light of the scarcity of novel therapeutic agents that are effective, the pharmaceutical industry has found a newer source of therapeutic compounds in natural products and herbal medicine to address the current health problems in humans and animals. What is particularly promising about these agents is that they produce fewer side effects and are more cost effective than synthetic compounds. This means greater availability of these treatments particularly for less developed countries who can't afford expensive treatments. The reduced side effects also mean greater patient tolerance and increased compliance thereby yielding maximal therapeutic effect without negatively impacting on quality of life. Among the natural products more frequently employed nowadays is propolis, a resin that is routinely collected by bees (Apis mellifera). Propolis contains flavonoids, caffeic acid esters and diterpenic acids, which provide the bactericidal, antiviral and antifungal properties to this product. The use of propolis to address a variety of conditions in small animal species is beginning to play an important role in the currently available treatments. Its use appears to be an effective treatment with no side effects at low cost. This paper reviews the different applications of this compound to treat diseases in dogs.
\end{abstract}

\section{Keywords}

Dog, Propolis, Uses, Treatments, Perspectives

\section{Introduction}

Since early ages, all living vertebrate species have interacted with pathogenic microorganisms that caused sev-

How to cite this paper: Tovar Betancourt, N., García-Contreras, L. and Cruz Sánchez, T.A. (2015) Propolis in Dogs: Clinical Experiences and Perspectives (A Brief Review). Open Journal of Veterinary Medicine, 5, 11-17. 
eral disease states; at that time nature provided its own solutions to maintain balance in the environment. With time and observation, human beings were able to identify the therapeutic effects of available plants and natural resources and developed a form of medicine known as "natural medicine." Natural medicine uses natural remedies for the treatment and prevention of disease states. Among the natural agents, propolis has been used in the treatment of disease. At the initial stages, the use of propolis in veterinary medicine was limited to antibacterial applications, but as time went by, newer applications were discovered for this product used by bees.

Propolis is a resin collected by bees from plants and trees in their surrounding environment. This product is used by the bees in order to close the combs inside of the hive, buttress the walls, and provide greater support to the hive's panels. It is also used to embalm their natural enemies and dead bee bodies that are too large for the bees to remove from the hive. A major function of propolis is to protect the hive of infectious disease that threatens the colony [1]. In the process of collecting, transporting, and storing the propolis, the bees add enzymes that confer invaluable therapeutic properties in veterinarian medicine, but also in human medicine. The presence of flavonoid compounds, caffeic acid esters and diterpenic confers its bacteriostatic, bactericidal, antiviral and fungicidal properties to this product. This has been exhaustively documented in vitro and in vivo studies [2].

In veterinary medicine, propolis is used in a variety of circumstances as described below. For example, propolis is used as ointment to control mastitis in milking cows. In pig herds, it is used as a prophylactic agent for respiratory and gastrointestinal diseases by adding $5 \%$ propolis to milk. It is also used as a stimulant for the growth of under developing rams, pigs, and calves. Other uses can be as a prophylaxis to counteract typhoid fever in ducks, wounds healing, and as a local anesthetic for surgery. Notably, in the canine species, the use of propolis has had a number of effective applications that are reviewed below [2].

\section{Uses and Perspectives of Propolis in Dogs}

\subsection{Neoplasia}

\subsubsection{Transmissible Venereal Tumor}

Propolis has been used in oncology for the treatment of transmissible venereal tumors (TVTs). TVT is a contagious neoplasia that is transmitted sexually and it only affects canines. The origin of TVT is unclear, spread throughout the world, but is most frequently seen in tropical and subtropical regions. There is no existing genetic or racial predisposition for TVT but the greatest prevalence of this disease is observed in animals during their reproductive age. It is diagnosed primarily through cytology or by histological exam. A cytological evaluation of a hypodermic needle used to sample TVT reveals the presence of abundant oval and round cells. TVT can metastasize and be found outside of the genital region. TVT has been treated with chemotherapy with the disadvantage of the unwanted side effects and in many cases the tumor grows back at the same place or is resistant to this treatment [3].

Studies performed in Brazil by Bassani-Silva et al. [3] evaluated the use of propolis to treat TVT by applying different concentrations of propolis to TVT cells obtained through a biopsy of infected dogs and observing its effects after 6, 24, and 48 hours post-exposure. After six hours, researchers observed significant antiretroviral activity and a significant reduction in viral load, but the effect was transient [3]. In addition to the compounds mentioned previously, the Brazilian propolis is reported to have Artepilin C, which appears to have a significant cytotoxic activity against tumor cells in vitro. This cytotoxicity was related with the fragmentation of DNA and the induction of apoptosis [3].

\subsubsection{Canine Osteosarcoma}

Another form of propolis that has been investigated is geopropolis [4] that is employed in the elimination of Canine Osteosarcoma (OSA) cells. Geopropolis is produced by bees without stingers (Melipona fasciculate Smith), which collect the resin of plants and add soil or clay to it. The actual biological properties of geopropolis or the additives have not been specifically identified as is the case of the propolis produced by Apis mellifera. However, it has been suggested to have antimicrobial, anti-inflammatory, and anti-tumoral activity. Even though a number of studies had aimed to study its antitumor activity, little is known about the cytoxic activity of geopropolis with OSA, a malignant tumor common among dogs. Canine OSA has many similarities with osteosarcoma found in human pediatric patients. Thus, OSA studies in dogs may be useful to evaluate its use in the treatment of this disease in humans. Costa Cinegaglia et al. [4] studied the effect of incubating geopropolis with osteosarcoma 
cells at different concentrations and exposure times (50 $\mu$ g for 6 and $24 \mathrm{~h}$; and $10 \mu \mathrm{g}$ for 48 and $72 \mathrm{~h}$ ). They concluded that osteosarcoma cells were susceptible to the effects of geopropolis at all concentrations and all times.

\subsubsection{Cushing's Syndrom}

Cushing's syndrome in dogs is usually caused by a neoplasm in the adrenal glands or pituitary gland. It is reported that the use of propolis in water (WPP) may be an alternative treatment. In four dogs with different stages of this syndrome, without pretreatment, WPP were administered orally ( 0.4 - 0.5 g crude propolis per $\mathrm{kg}$ body weight) every 12 hours for three months. Of these, upon completion of treatment, three had a full recovery. This demonstrates the utility that WPP may have [5].

\subsection{Bacterial Infections}

Among the bacteria that cause disease in dogs, Staphylococcus aureus is of great importance. Bacteria in this genus are considered saprophyte bacteria on the skin and in mucosal surfaces in animal and in men. Infections with Staphylococcus species are classified by their pathogenicity as coagulase negative (e.g., S. epidermidis, S. saprophyticus) and coagulase positive (e.g., S. aureus, S. intermedius and S. hycus). More than $60 \%$ of the pyogenic infections on the skin, known as pyoderma of the skin in dogs, are caused by coagulase positive species, particularly S. aureus and S. intermedius. These are considered the causative pathogens of the disease and could possibly lead to development of chronic or recurrent pyoderma, which in turn can result in a secondary infection caused by Pseudomonas species, Proteus species and Escherichia coli [6].

Dogs are considered reservoirs of drug-susceptible bacteria and drug-resistant bacteria such as $S$. aureus. This has led to research new alternative treatments, one of them being ethanolic extracts of propolis for topical applications, an alternative that has proven to be effective and inexpensive [7]. Exposure of S. aureus to ethanolic extracts of propolis (20\% - 40\%) was effective in these concentrations [8]. However, this effect was modest when compared to the inhibition of bacterial growth by penicillin [6].

\subsection{Canine Otitis}

Otitis External (OE), commonly known as an "ear infection", is a condition characterized by the inflammation of the external auditory canal. Infections of the ear are one of the main reasons that a dog is taken to the veterinarian for treatment. Dogs diagnosed with OE often exhibit inflammation and erythema in the epithelial tissue of the external auditory canal. There is also an increase in wax secretion by the ear glands, itching, and changes in behavior. Environmental factors such as hot weather and humidity can influence the incidence of $\mathrm{OE}$ in dogs [9]-[11].

Malassezia pachydermatis is the yeast most commonly isolated from cultures of patients affected by $\mathrm{OE}$, whereas Candida spp. is observed infrequently in the exudate of dogs with OE. In the majority of the samples, Malasezia pachydermatis is associated with S. aureus, which confirms the symbiosis between these two microorganisms. It has been demonstrated that the application of topical extracts of propolis is a new therapy for the treatment of $\mathrm{OE}$ in dogs. This is no surprise given the wide antimicrobial spectrum, an anti-inflammatory effect of this compound, with the added bonus of being inexpensive and free of side effects. Thus, a formulation for ear drops that has sufficient viscosity to remain in the ear would be desirable for the treatment of Otitis External [10].

\subsection{Dermatophytosis}

This is a superficial infection of the skin caused by pathogenic dermatophytes of the genus Epidermophyton, Trichophyton, and Microsporum. Dermatophytes live in keratinized tissue such as nails, hair follicles, hair and the stratum corneum of the skin. These pathogens are very important clinically because of its high zoonotic potential. Several treatments have been proposed to treat these diseases, but most of them are inefficient or cause collateral effects. New antimycotic treatments have incorporated natural compounds such as propolis. These treatments have reported to effective in three dogs with dermatophytosis. After diagnosis, the treatment for the dogs consisted of weekly baths with a commercial soap made with propolis for 3 to 8 weeks plus application of a topical ointment all days for three weeks. After two weeks of treatment, all bacterial cultures were negative and by the end of the treatment the three dogs recovered from their lesions. This demonstrated that the use of alter- 
native antimycotic compounds such as propolis would limit the development of infections by Microsporum [12].

\subsection{Parasitosis}

Giardiasis and Trypanosomiasis are parasitic infections experienced by dogs and cats. The use of propolis and metronidazol was evaluated in mice infected with Giardia lamblia. The combined therapy showed a stronger efficacy in reducing the parasitic count than that gained by each drug alone. The use of propolis alone significantly reduced the intensity of infection and elicited a significant increase in the serum levels of cytokines and interferon gamma. However, the synergistic effect of both compounds resulted in an immunological balance that was more balanced in terms of the T-lymphocyte profile that protected the intestinal homeostasis and histological architecture [13].

Gressler et al. [14] studied the susceptibility of T. evansi to propolis in infected rats. Propolis was administered orally to these rats at doses of $100-400 \mathrm{mg} / \mathrm{kg}$ daily for ten days. Even though all rats eventually of the disease, those treated with the highest dose lived twice as long as those treated with the smallest dose indicating that the propolis extract can prolong life in rats infected with the protozoan. These studies suggest that propolis may be of use in treating small species infected with $T$. evansi.

\subsection{Enhancement of the Immune Response}

Immunization or vaccination aims to prevent or decrease the signs and symptoms of a determined disease in animals or humans. However, often vaccines by themselves are not capable of elicit a robust or protective immune response and requires the use of adjuvants. These compounds increase or enhance the immunogenicity of the antigen in the vaccine and increase the protective period of the vaccine. It is also possible that the addition of adjuvants to vaccine formulations may allow decreasing the amount of the antigen required to elicit a protective immune response or increase the duration of the protective effect.

The ideal adjuvant should enhance the cellular and humoral immune responses and have little to non-biological activity by itself and if possibly, be biodegradable and inexpensive. Most of the adjuvants currently in use do not fulfill all these requirements and research efforts are being directed to find other sources of adjuvants, such as natural products. One of the many properties of propolis is to be able to enhance the immune response [15].

Recent studies have demonstrated that the addition of the ethanolic extract of propolis to the canine parvovirus vaccine $(\mathrm{CPV})$ and canine coronavirus $(\mathrm{CCoV})$ enhanced the production of antibodies against these pathogens in rats. IgG was measured in the serum of immunized animals 21 days after the third dose. Titers indicated that the addition of propolis improved the serum specificity of IgG toward CPV in animals immunized with the highest antigen dose without influencing the antibodies against $\mathrm{CCoV}$. These results indicate that propolis has an immunomodulatory activity that is dependent of the type and concentration of the used antigen, as demonstrated by increasing antibody titers against CPV. Other studies show a similar enhanced immunity in the case of canine distemper [15] [16].

\subsection{Periodontal Disease}

The potential effect of propolis in the treatment of periodontal disease among dogs should not be overlooked. Having a prevalence of $80 \%$, it is the most common oral disease in dogs. This disease is progressive and has two stages: gingivitis (reversible) and periodontitis (irreversible). It is caused by the accumulation of plaque on the teeth. The plaque is a smooth layer formed by bacteria, non-living particulate organic material, cell debris and contaminated saliva. Bacteria and the product of their metabolism cause inflammation of the soft tissue. Plaque buildup can become mineralized and form calculus or tartar that can pass through the gingiva, causing inflammation followed by the loss of the periodontal ligament, loss of bone, and finally the loss of the teeth. This disease process should be prevented to avoid problematic infections. Chlorhexidine has been shown to have great efficacy in preventing the formation of oral plaque and it has a strong antiseptic activity against oral pathogens. However it has the disadvantage of staining the enamel and can cause ulcerations in the mucosa and for this reason should only be used for a few days. This limits the use of chlorhexidine as a true preventive antimicrobial agent that prevents plaque formation. Veterinarians typically mix xylitol with the pet's drinking water in order to reduce the formation of oral bacterial plaque [17]. 
Research in this area has suggested that natural products such as propolis may be of use to prevent periodontal disease. These studies indicate that propolis prevents periodontal disease by inhibition of plaque formation. It is worth noting that the antibacterial activity of these compounds is not through mechanisms that may induce bacterial resistance but instead they inhibit the attachment of the bacteria to the surface of the tooth. Studies have demonstrated that the use of ethanol extracts of propolis in the dental cavity of dogs reduces inflammation, reorganizes tissue on the surface level, and reduces bacterial activity [18]. This suggests that propolis may be of use as oral antiseptic without causing side effects [19] [20].

\subsection{Ophthalmopathies}

Due to the numerous medicinal properties of propolis, it is not surprising that it has also been employed in the effective treatment of ocular diseases among humans and animals. It has been used in cats and dogs that suffer from blepharitis, infectious conjunctivitis, corneal edema, tear duct obstruction, keratoconjunctivitis sicca, corneal ulcers, and glaucoma [21]. The usefulness of propolis in ophthalmic preparations was demonstrated in a study performed with 25 dogs and 5 cats that had ocular diseases. Unlike animals treated with alopatic eyewashes, those treated with propolis healed in 5 - 7 days for acute cases and in 10 - 15 days for chronic cases. Thus, propolis may be a promising therapeutic compound to treat ophthalmic diseases effectively, without side effects and at low cost [22].

\subsection{Liver Diseases}

Apiarian products have also been employed in the treatment of liver diseases. A mixture of bee pollen and propolis with a plant extract, microelements and vitamins was administered alone or in various dosing regimens according to the extent of liver disease. Clinical evaluations were performed in dogs of various ages and breeds diagnosed with hepato-billiary diseases (liver insufficiency, acute hepatitis, liver cirrhosis, and cholestasis). The methods of nutritional therapy with the mixture of bee products and plant extract were at least as effective as the standard treatment methods [23].

Table 1. Clinical studies and possible uses of propolis in dogs.

\begin{tabular}{|c|c|c|c|}
\hline Therapeutic property & Disease or Causative microorganism & Type of evidence & References \\
\hline \multirow[t]{6}{*}{ Antimicotic } & Canine otitis & & \\
\hline & Malassezia pachydermatis & Clinical experience & {$[10][11]$} \\
\hline & Candida spp. & & \\
\hline & Dermatophytosis & & \\
\hline & Microsporum canis & Clinical experience & {$[12]$} \\
\hline & Microsporum gypseum & & \\
\hline \multirow[t]{3}{*}{ Antineoplasic } & Transmissible venereal tumor & \multirow{2}{*}{ Experimental (in vitro) } & {$[3]$} \\
\hline & Osteosarcoma & & [4] \\
\hline & Cushing’s syndrome & Clinical experience & {$[5]$} \\
\hline \multirow[t]{2}{*}{ Bactericide } & Staphylococcus aureus & & \\
\hline & $\begin{array}{c}\text { Pseudomonas ssp. } \\
\text { Proteus ssp. } \\
\text { Escherichia coli }\end{array}$ & Experimental (in vitro) & {$[6]-[8]$} \\
\hline \multirow[t]{2}{*}{ Immunoestimulant } & Canine distemper & \multirow{2}{*}{ Experimental (in vitro, in vivo in mice) } & {$[16]$} \\
\hline & Canine parvovirus & & {$[15]$} \\
\hline \multirow[t]{4}{*}{ Oftalmic } & Blefaritis & & \\
\hline & Conjuntivitis & Clinical exnerienco & {$[20][21]$} \\
\hline & Queratoconjuntivitis & Clinical experience & \\
\hline & Glaucoma & & \\
\hline \multirow[t]{2}{*}{ Paradontal } & Gingivitis & \multirow{2}{*}{ Clinical experience } & \multirow{2}{*}[17]{$-[19]$} \\
\hline & Paradontitis & & \\
\hline Metabolic & Liver diseases & Clinical experience & {$[22]$} \\
\hline \multirow[t]{2}{*}{ Antiparasitic } & Giardiais & Experimental (in vitro in rats) & {$[13]$} \\
\hline & Trypanosomiasis & Experimental (in vitro in mice) & [14] \\
\hline
\end{tabular}




\section{Summary and Conclusion}

It is important to keep in mind that in vitro tests do not reflect the real conditions found in infections in the animals or patients in the clinic. Such tests at best establish the conditions and justifications for in vivo studies which may at some point result in the development of commercial products to treat different diseases (Table 1). Propolis is a natural medication with a promising future, but additional studies are required to assess its usefulness in veterinary medicine.

\section{Acknowledgements}

The authors express their gratitude to the UNAM DGAPA projects PAPIT IT223811-3, IT200915, FESC PIAPIC28 and support by CONACYT 639757.

\section{References}

[1] Kuropatnicki, A.K., Szliszka, E. and Krol, W. (2013) Historical Aspects of Propolis Research in Modern Times. Evidence-Based Complementary and Alternative Medicine, 2013, Article ID: 964149. http://dx.doi.org/10.1155/2013/964149

[2] Bogdanov, S. (2014) Propolis: Composition, Health, Medicine: A Review. Bee Product Science, 1-40. http://www.bee-hexagon.net/files/file/fileE/Health/PropolisBookReview.pdf

[3] Bassani-Silva, S., Sforcin, J.M., Amaral, A.S., Gazpar Luiz, F.J. and Rocha Noeme, S. (2007) Propolis Effect in Vitro on Canine Transmissible Venereal Tumor Cells. Revista Portuguesa de Ciências Veterinárias, 102, 261-265. www.fmv.utl.pt/spcv/PDF/pdf12 2007/261-265.pdf

[4] Costa Cinegaglia, N., Oliveira Bersano, P.R., Mendes Araújo, M.J.A., Cristiane Búfalo, M. and Sforcin, J.M. (2013) Anticancer Effects of Geopropolis Produced by Sting Less Bees on Canine Osteosarcoma Cells in Vitro. Evidence-Based Complementary and Alternative Medicine, 2013, Article ID: 737386. http://dx.doi.org/10.1155/2013/737386

[5] Perry, G. (2006) The Veterinary Use of Water Preparation of Propolis. ApiMedica. http://www.wholepropolis.com/APIMEDICA\%20\%20VET\%20PROPOLIS.pdf

[6] Gross, G.S., Carvajal, I.L.C. and Principal, J. (2007) Perfil de flavonoides e índices de oxidación de algunos propóleoscolombianos. Zootecnia Tropical, 25, 95-102. http://www.sian.inia.gob.ve/repositorio/revistas_ci/ZootecniaTropical/zt2502/pdf/salamanca.pdf

[7] Mayta Tovalino, F. and Sacsaquispe Contreras, S. (2010) Evaluación in Vitro del efecto antibacteriano del extracto etanólico de propóleo de Oxapampa-Perú sobre cultivos de Streptococcus mutans (ATTC 25175) y Staphylococcus aureus (ATCC 25923). Revista de Estomatologia Herediana, 20, 19-24. http://www.upch.edu.pe/vrinve/dugic/revistas/index.php/REH/article/viewFile/1777/1793

[8] Principal, J., Barrios, C., Tahís Pacheco, N., Corrales, F. and Moreno, F. (2005) Actividad antibacteriana in Vitro del extracto etanólico de propóleo sobre una cepa clínica de Staphylococcus aureus. Gaceta de Ciencias Veterinarias, 11, 31-36.

http://www.ucla.edu.ve/dveterin/departamentos/CienciasBasicas/gcv/2530int2530er2530no/articulos/documasp/ keh3 d2oa.pdf

[9] Lozina, L., Boehringer, S., D’Aquino, M. and Acosta, O. (2006) Eficacia del Propóleos sobre Malassezia pachydermatis. Correlación de distintas Técnicas in Vitro. Acta Farmacéutica Bonaerense, 25, 560-563. http://www.latamjpharm.org/trabajos/25/4/LAJOP $25 \quad 4 \quad 2 \quad 1$ PHJ4JJDVSS.pdf

[10] Lozina, L.A., Peichoto, M.E., Boehringer, S.I., Koscinczuk, P., Granero, G.E. and Acosta, O.C. (2010) Efficacy of Argentine Propolis Formulation for Topical Treatment of Canine Otitis Extern. Arquivo Brasileiro de Medicina Veterinária e Zootecnia, 62, 1359-1366. http://dx.doi.org/10.1590/S0102-09352010000600010

[11] Cardoso, R.L., Maboni, F., Machado, G., Hartz, A.S. and Castagna de Vargas, A. (2010) Antimicrobial Activity of Propolis Extract against Staphylococcus Coagulase Positive and Malassezia pachydermatis of Canine Otitis. Veterinary Microbiology, 142, 432-434. http://dx.doi.org/10.1016/j.vetmic.2009.09.070

[12] Cruz Sánchez, T.A., Estrada García, P.A., López Zamora, C.I., Autran Martínez, M., Pérez Valencia, V. and Londoño Orozco, A. (2014) Use of Propolis for Tipical Treatment of Dermatophytosis in Dog. Open Journal of Veterinary Medicine, 4, 239-245. http://dx.doi.org/10.4236/ojvm.2014.410028

[13] Abdel-Fattah, N.S. and Nada, O.H. (2007) Effect of Propolis versus Metronidazole and Their Combined Use in Treatment of Acute Experimental Giardiasis. Journal of the Egyptian Society of Parasitology, 37, 691-710 http://www.ncbi.nlm.nih.gov/pubmed/17926808 
[14] Lucas, T.G., Da Silva, A.S., Machado, G., Dalla Rosa, L., Dorneles, F., Gressler, T.L., Oliveira, M.S., Zanette, R.A., Agueda de Vargas, C.P. and Monteiro, S.G. (2012) Susceptibility of Trypanosoma evansi to Propolis Extract in Vitro and in Experimentally Infected Rats. Research in Vetrinary Science, 93, 1314-1317. http://dx.doi.org/10.1016/j.rvsc.2012.02.007

[15] Ferreira, L.N., Fonseca, F.P., Caetano de Castro, C., Sica Siedler, B., Silveira Munhoz, L., D’Avila Vargas, G., Fischer, G. and Oliveira Hubner, S. (2012) Effect of the Etanolic Extract from Green Propolis on Production of Antibodies after Immunization against Canine Parvovirus (CPV) and Canine Coronavirus (CCoV). Brazilian Journal of Veterinary Research and Animal Science, 49, 116-122. http://www.revistas.usp.br/bjvras/article/viewFile/40267/43133

[16] El Ashry, E.S.H. and Ahmad, T.A. (2012) Review the Use of Propolis as Vaccine’s Adjuvant. Vaccine, 31, 31-39. http://dx.doi.org/10.1016/j.vaccine.2012.10.095

[17] Pieri, F.A., Falci, A.P., Bourguignon, E. and Scatamburlo Moreira, M.A. (2012) Periodontal Disease in Dogs. In: Perez-Marin, C.C., Ed., A Bird's-Eye View of Veterinary Medicine, In Tech, Croctia, 119-136. www.intechope.com

[18] Ilewicz, L., Luciak, M., Skrobidurska, D., Scheller, S. and Stojko, A. (1979) The Effect of Ethanol Propolis Extracts on the Dental Pulp in Dogs. Czasopismo Stomatologiczne, 32, 321-329. http://www.ncbi.nlm.nih.gov/pubmed/287596

[19] Ahuja, V. and Ahuja, A. (2011) Apitherapy_A Sweet Approach to Dental Diseases. Part II: Propolis. Journal of Academy of Advanced Dental Research, 2, 1-8. http://www.joaor.org/userfiles/Vol-2-Issue-2-May-Aug-2011/01Ahuja.pdf

[20] Dantas de Almeida, L.F., Wanderley Cavalcanti, B.Y., Lira Junior, B.R., Oliveira Lima, E. and Dias de Castro, R. (2012) Efecto antimicótico de las tinturas a partir del propóleo y pomegranate contra las especies de Candida. Revista Cubana de Estomatología, 26, 99-106. http://scielo.sld.cu/pdf/est/v49n2/est03212.pdf

[21] Alfaris, A.A., Abdulsamadm, R.K. and Swadm, A.A. (2009) Comparative Studies between Propolis, Dexametason and Gentamycin Treatments of Induced Corneal Ulcer in Rabbits. Iraqi Journal of Veterinary Sciences, 23, S75-S80. http://vetmedmosul.org/ijvs

[22] Giral, T., Hugues, B. and Soto, C.J. (2007) Suspensión oftálmica de propóleos-R: Una alternativa en el tratamiento de las oftalmopatias en animales afectivos. Revista Electrónica de Clínica Veterinaria, 2, 1-6. http://www.veterinaria.org/revistas/recvet/n090907.html

[23] Monteescu, C., Sayuu, S., Crenguta, P., Ion, R., Sapcaliu, A., Cauia, E. and Siceanu, A. (2011) Apiphytotherapeutic Product Used for Nutritional Therapy in Dogs with Liver Disease. Economics, Management, and Financial Markets, 6, 1175-1178.

http://connection.ebscohost.com/c/articles/97464414/apiphytotherapeutic-product-used-nutritional-therapy-dogs-liverdiseases 
Scientific Research Publishing (SCIRP) is one of the largest Open Access journal publishers. It is currently publishing more than 200 open access, online, peer-reviewed journals covering a wide range of academic disciplines. SCIRP serves the worldwide academic communities and contributes to the progress and application of science with its publication.

Other selected journals from SCIRP are listed as below. Submit your manuscript to us via either submit@scirp.org or Online Submission Portal.
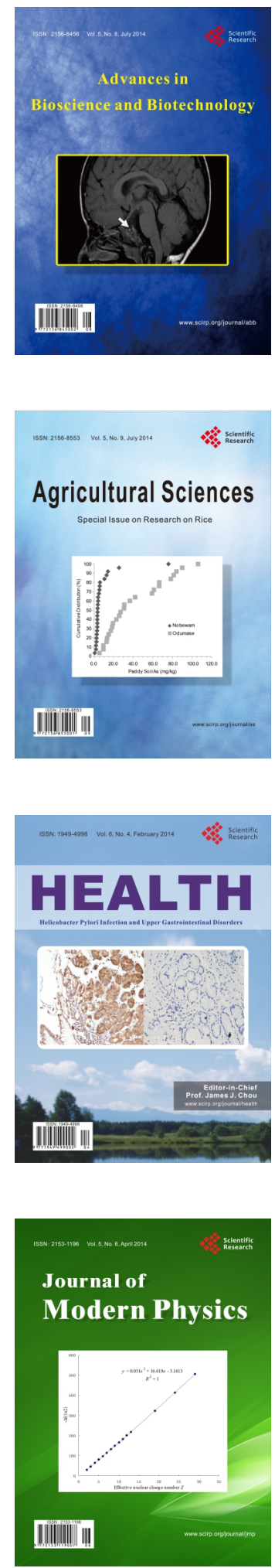
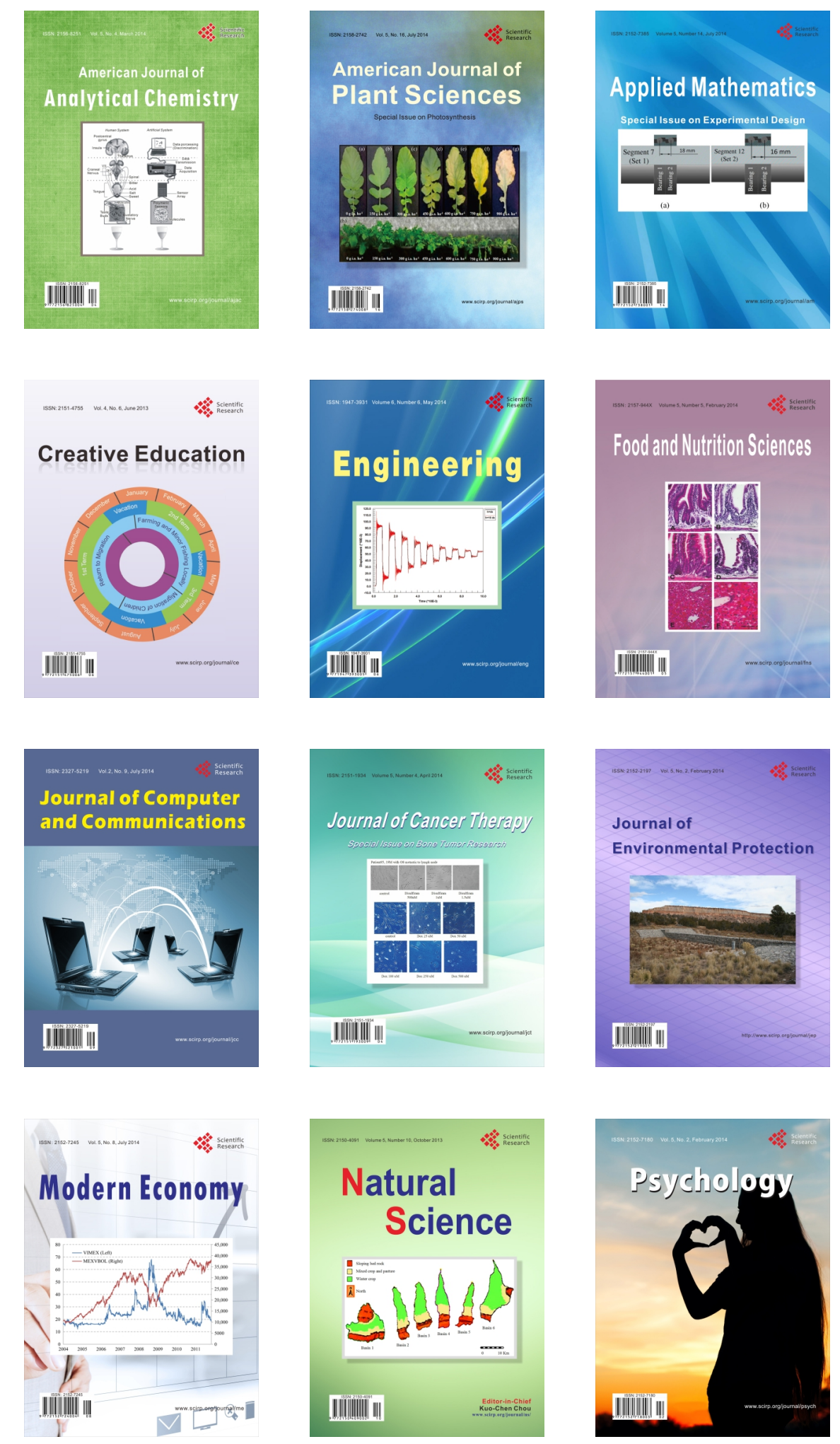